\title{
Tinjauan Yuridis Penerapan Dan Pelaksanaan Hukuman Mati Terhadap Pelaku Tindak Pidana Pengedar Narkotika Berdasarkan Undang-Undang Nomor 35 Tahun 2009 Tentang Narkotika
}

\author{
Nys. Arfa, Syofyan Nur, Yulia Monita \\ Fakultas Hukum, Universitas Jambi, Indonesia
}

\begin{abstract}
ABSTRAK
Pengaturan tindak pidana narkotika di Indonesia berdasarkan pada Undang-Undang Nomor 35 Tahun 2009 Tentang Narkotika. Dalam undang-undang tersebut diatur tentang ancaman pidana bagi pelaku tindak pidana narkotika salah satunya terhadap pengedar narkotika. Adapun ketentuan yang mengatur tentang sanksi pidana bagi pengedar narkotika tersebut diatur pada Pasal 114 yang mana pada ayat (2) disebutkan salah satu ancaman pidananya adalah pidana mati. Permasalahan adalah bagaimana penerapan hukuman mati terhadap pelaku tindak pidana pengedar narkotika berdasarkan Undang-Undang Nomor 35 Tahun 2009 Tentang Narkotika dan bagaimana kebijakan hukum pidana ke depan dalam pelaksanaan pidana mati bagi pelaku tindak pidana pengedar narkotika?. Metode yang dipergunakan dalam penelitian ini adalah metode penelitian hukum normatif, pendekatan penelitian yang digunakan adalah pendekatan undang-undang, pendekatan konseptual, dan pendekatan kasus. Hasil penelitian bahwa Penerapan hukuman mati bagi pengedar narkotika di Indonesia berdasarkan Undang-Undang Nomor 35 Tahun 2009 Tentang Narkotika telah sesuai dengan hukum positif yang berlaku di negara Indonesia, yakni sesuai dengan Pasal 10 KUHP. Penerapan hukuman mati bagi pelaku tindak pidana pengedar narkotika masih relevan dilaksanakan saat ini, hal tersebut dilakukan untuk menyelamatkan generasi penerus bangsa dan menyelamatkan bangsa dan negara Indonesia dari kehancuran yang diakibatkan oleh penyalahgunaan narkotika. Yang menjadi permasalahan saat ini adalah tidak adanya aturan yang mengatur mengenai batas waktu pelaksanaan eksekusi mati bagi terpidana mati di Indonesia, sehingga hal tersebut dapat menimbulkan ketidakpastian hukum bagi masyarakat terutama bagi terpidana mati itu sendiri, khususnya terpidana mati tindak pidana pengedar narkotika. Kebijakan kedepan dalam pelaksanaan pidana mati bagi pengedar narkotika masih perlu dilaksanakan karena hal tersebut telah sesuai dengan hukum dan undang-undang yang berlaku di Indonesia. Pelaksanaan eksekusi mati sebaiknya dilakukan setelah siterpidana mati melakukan semua upaya hukum dalam batas waktu 5 tahun.
\end{abstract}

Kata Kunci: Penerapan hukuman mati, pengedar narkotika

\section{PENDAHULUAN}

Upaya pemerintah untuk memerangi penyalahgunaan narkotika tampak semakin serius. Hal ini disebabkan karena Indonesia dikatakan telah mengalami darurat narkotika. Ini tentu beralasan karena hampir setiap waktu jumlah orang yang meninggal akibat penyalahgunaan narkotika semakin tinggi. Korbannya bukan saja dari kalangan dewasa, namun juga remaja, bahkan anak-anak. Salah satu upaya pemerintah ialah dengan menerapkan hukuman mati bagi bandar dan pengedar narkotika.

Sekalipun demikian, upaya pemerintah dalam menerapkan pidana mati bagi bandar dan pengedar narkotika justru memunculkan pro dan kontra di kalangan masyarakat Indonesia, bahkan juga penentangan dari negara lain. Di Indonesia, 
Komisi Nasional Hak Asasi Manusia tegas menyatakan penolakan atas penerapan hukuman mati di Indonesia.

Mereka yang menolak penerapan hukuman mati biasanya bertolak dari prinsip umum yang terdapat dalam UUD 1945 dan Undang-Undang mengenai hak asasi manusia. Sementara, mereka yang mengusung hukuman mati lebih melihat akibat yang ditimbulkan oleh penyalahgunaan narkotika yang menimbulkan korban yang teramat luas. Oleh karenanya, menyikapi pro dan kontra terhadap penerapan hukuman bagi bandar dan pengedar narkotika diperlukan pandangan dan sikap yang arif sehingga diperoleh kesepakatan mengenai penerapan pidana mati tersebut, terutama terhadap pengedar.

Pada dasarnya, hukuman mati merupakan salah satu sanksi pidana yang masih berlaku di negara Indonesia. Ini artinya bahwa penerapan hukuman mati masih diperbolehkan khusus bagi tindak pidana tertentu, seperti pembunuhan berencana, terorisme, korupsi, termasuk kejahatan narkotika, sebagaimana terdapat dalam undang-undang yang berlaku (hukum positif) di Indonesia.

Konsep hak asasi manusia yang paling esensial adalah hak untuk hidup serta melangsungkan kehidupan. Ia menjadi asasi karena ia dianggap sebagai pemberian langsung oleh Tuhan kepada manusia. Karenanya, siapapun orang memiliki hak untuk mempertahankan kehidupannya dan membela diri dari segala hal yang dapat merusak kehidupannya. Demikian pentingnya, maka setiap upaya yang ingin merampas kehidupan seseorang (misalnya dengan membunuh, termasuk pidana mati) pada dasarnya bertentangan dengan hak asasi manusia, jika hal tersebut dilakukan secara semena-mena tanpa ada sandaran (hukum) yang dapat dibenarkan. Karenanya, segala upaya merampas kehidupan baik dengan cara dibunuh ataupun dihukum mati, yang dilakukan secara sewenang-wenang, hal tersebut merupakan hal yang terlarang." 1

Kendati demikian, merampas hak hidup seseorang itu diperkenankan jika hal tersebut terpaksa dilakukan. Karenanya, pidana mati dianggap sebagai jalan yang paling akhir dari sanksi pidana. ${ }^{2}$ Itupun setelah melewati prosedur yang begitu ketat. Bahkan dalam posisi dimana hukuman mati layak diberikan, seorang pelaku (terpidana) masih diberikan haknya untuk mendapatkan pengampunan, peringanan, penundaan, atau perubahan/penggantian pidana mati setelah melewati masa tertentu. ${ }^{3}$

68.

${ }^{1}$ Periksa Barda Nawawi Arief,Kebijakan Hukum Pidana, Jakarta: Prenada Media Group, 2011, hlm.

${ }^{2}$ Seperti diatur dalam Undang-Undang Nomor 35 Tahun 2009 Tentang Narkotika, sanksi pidana itu bervariasi dari pidana pokok (denda, kurungan, penjara dalam waktu tertentu/seumur hidup, dan pidana mati), pidana tambahan (pencabutan izin usaha/pencabutan hak tertentu), hingga tindakan pengusiran bagi warga negara asing. Lihat Barda Nawawi Arief, Masalah Penegakan Hukum dan Kebijakan Hukum Pidana Dalam Penanggulangan Kejahatan, Jakarta: Prenada Media Group, 2010, hlm. 194.

${ }^{3}$ Barda Nawawi Arief, Kebijakan....., hlm.69. 
Sejumlah ahli hukum pidana menyarankan bahwa dipertahankannya pidana mati itu pada dasarnya bertolak dari fakta akan adanya reaksi yang mungkin muncul dari masyarakat yang berpotensi mengambil langkah sendiri secara sewenang-wenang dan anarkis (extralegal execution). Karenanya itu, diterapkannya pidana mati dalam suatu undang-undang bertujuan untuk memberi rasa dimaksudkan untuk memberikan saluran emosi dari masyarakat. Guna menghindari emosi dan balas dendam pribadi maupun kolektif dari masyarakat secara semena-mena, adalah bijaksana bilamana pidana mati tetap diatur dalam undang-undang. Hal ini juga bertujuan sebagai perlindungan terhadap individu maupun masyarakat dari kemungkinan aksi balas dendam dari pihak korban yang merasa tidak mendapatkan keadilan. ${ }^{4}$ Penerapan pidana mati, menurut Barda Nawawi Arief tidak bertentangan dengan prinsip "hak untuk hidup" sebagaimana diatur pada Pasal 28A jo. Pasal 28 I UUD 1945 dan Pasal 9 Ayat (1) jo. Pasal 4 Undang-Undang Nomor 39 Tahun 1999 Tentang HAM dan "hak untuk bebas dari penghilangan nyawa" dalam Pasal 33 nya. Sekalipun dalam ICCPR dinyatakan "setiap manusia mempunyai hak untuk hidup", namun hal tersebut bukan bermakna hak hidup seseorang tidak dapat direnggut. Yang dilarang, menurut Barda Nawawi Arief, adalah merampas hak hidup dengan sewenang-wenang. ${ }^{5}$

Uraian di atas memberikan gambaran terhadap pidana mati adalah bisa diterapkan terhadap tindak pidana tertentu dimana dianggap sangat membahayakan bagi masyarakat atau dapat menimbulkan keresahan yang tinggi. Penerapan hukuman mati boleh dilakukan asalkan telah diatur dalam undangundang dan tidak dipandang pantas untuk tetap dipertahankan. Ditambah adanya dukungan dari mayoritas masyarakat terhadap penerapan pidana mati tersebut terhadap pelaku tindak dilakukan secara sewenang-wenang.

Terdapat sejumlah pasal dalam Undang-Undang Narkotika tentang ketentuan pidana mati terhadap pelaku penyalahgunaan narkotika, yaitu pada ayat (2) dari masing-masing Pasal 113, Pasal 114, Pasal 116, Pasal 118, Pasal 119, Pasal 121, dan Pasal 133 pada Ayat (1) nya. Akan tetapi, terhadap pengedar narkotika diancam hukuman mati sebagaimana diatur Pasal $114 .{ }^{6}$ Sejumlah pasal ini menginformasikan bahwa pidana mati hanyalah salah satu dari ancaman pidana yang mungkin dijatuhkan terhadap pengedar narkotika. Itupun terhadap orang yang mengedarkan narkotika golongan tertentu.

Disahkannya Undang-Undang Narkotika di Indonesia di dasarkan pada Konvensi PBB pada Tahun 1988 tentang Pemberantasan Peredaran Gelap Narkotika dan Psikotropika. Pemerintah Republik Indonesia mengajak semua elemen

\footnotetext{
${ }^{4}$ Lihat ibid., hlm. 289.

${ }^{5}$ Ibid., hlm. 291.

${ }^{6}$ Selengkapnya lihat Pasal 114 Undang-Undang Nomor 35 Tahun 2009 Tentang Narkotika.
} 
masyarakat untuk berpartisipasi secara aktif dalam upaya pemberantasan peredaran gelap narkotika dan psikotropika. ${ }^{7}$

Diterapkannya pidana mati bagi para pelaku tindak pidana berat masih pidana berat atau tindak pidana luar biasa. Masyarakat memandang pidana mati sebagai pidana yang tepat untuk tindak pidana tertentu yang bertujuan memberikan efek jera terhadap pelaku tindak pidana tersebut, serta untuk menegakkan hukum dan menurunkan tingkat kejahatan dalam masyarakat. ${ }^{8}$

Pelaku tindak pidana narkotika yang dijatuhi dengan pidana mati dalam hal eksekusi atau pelaksanaan pidana tersebut terdapat beberapa permasalahan, diantaranya terkait dengan waktu pelaksanaan dari pidana mati tersebut sejauh ini tidak ada aturan yang mengatur ataupun dituangkan dalam undang-undang, hal ini menyebabkan ketidakjelasan terhadap terpidana mati tersebut dalam hal pelaksanaan pidananya. Seharusnya ada aturan yang mengatur ataupun dituangkan dalam undang-undang terkait dengan rentang waktu dalam pelaksanaan pidana mati tersebut secara jelas dan pasti.

Dari penjelasan di atas menggambarkan bahwa mengenai pelaksanaan dari pidana mati tersebut tidak adanya kejelasan atau kepastian hukum. Hal tersebut dikarenakan tidak adanya aturan yang mengatur tentang batas waktu pelaksanaan eksekusi mati bagi terpidana mati di Indonesia, sehingga hal tersebut dapat menimbulkan ketidak pastian hukum bagi si terpidana mati, dalam hal ini terpidana mati kasus tindak pidana pengedar narkotika.

Beranjak dari keadaan di atas maka penulis tertarik untuk melakukan kajian ilmiah tentang Yuridis Penerapan dan Pelaksanaan Hukuman Mati Terhadap Pelaku Tindak Pidana Pengedar Narkotika Berdasarkan Undang-Undang Nomor 35 Tinjauan Tahun 2009 Tentang Narkotika. Untuk membatasi kajian penelitian, maka permasalahan dibatasi pada persoalan yang dianggap sangat mendasar, yaitu:

1. Bagaimanakah penerapan pidana mati terhadap pelaku tindak pidana yang mengedarkan narkotika berdasarkan Undang-Undang Nomor 35 Tahun 2009 tentang Narkotika?

2. Bagaimanakah kebijakan hukum pidana ke depan dalam pelaksanaan pidana mati bagi pelaku tindak pidana pengedar narkotika?

\section{TINJAUAN PUSTAKA}

\section{Tindak Pidana Narkotika}

Mengenai perbuatan yang dilarang sebagai perbuatan penyalahgunaan narkotika diatur dalam Undang-Undang Narkotika pada Bab XV Pasal 111 sampai dengan 148 yang merupakan lex specialis.

\footnotetext{
${ }^{7}$ Siswanto,Politik Hukum dalam Undang-Undang Narkotika, Jakarta: PT. Rineka Cipta, 2012, hlm. 5.

${ }^{8}$ Siswanto Sunarso, Penegakan Hukum Psikotropika Dalam Kajian Sosiologi Hukum, Raja Grafindo Persada, Jakarta, 2004, hlm. 176.
} 
Berdasarkan Undang-Undang Nomor 35 Tahun 2009 Tentang Narkotika Bab XV ketentuan pidana, maka tindak pidana narkotika adalah sebagaimana yang diatur pada Pasal 111, Pasal 112, Pasal 113, Pasal 114, Pasal 115, Pasal 116, Pasal 117, Pasal 118, Pasal 119, Pasal 120, Pasal 121, Pasal 122, Pasal 123, Pasal 124, Pasal 125, Pasal 126, Pasal 127 Ayat (1), Pasal 128 dan Pasal 129. ${ }^{9}$

\section{Sanksi Pidana Mati Dalam Undang-Undang Narkotika}

Undang-Undang Narkotika mengatur 4 (empat) macam perbuatan melawan hukum menyangkut kejatahan narkotika yang oleh undang-undang dapat diancam dengan sanksi pidana, yaitumemiliki, memproduksi, menawarkan, atau membawa. ${ }^{10}$

Berdasarkan Pasal 10 Kitab Undang-Undang Hukum Pidana (KUHP) terdapat beberapa jenis sanksi pidana, yaang terdiri dari pidana pokok dan pidana tambahan. Pidana pokok meliputi pidana mati, penjara, kurungan dan denda. Sedangkan pidana tambahan berupa pencabutan hak yang tertentu, perampasan barang tertentu, dan pengumuman keputusan hakim. ${ }^{11}$

Pidana mati tampaknya masih dipertahankan dan berlaku di Indonesia karena memang hal tersebut telah ditentukan dan diatur secara jelas dalam beberapa undang-undang, terutama sekali dalam KUHP atau Kitab Undang-Undang Hukum Pidana. Undang-Undang Narkotika bahkan dengan tegas menjadikan pidana mati seabagai salah satu ancaman pidana, khususnya bagi mereka yang memproduksi dan mengedar narkotika. ${ }^{12}$

Ada beberapa ketentuan yang diatur pada Undang-Undang Narkotika tentang sanksi pidana mati terhadap pelaku penyalahgunaan narkotika, yaitu Ayat (2) dari Pasal 113, 114, 116, Pasal 118, 119, 121, dan Pasal 133 Ayat (1). Adapun ketentuan mengenai ancaman pidana terhadap pelaku pengedar narkotika yaitu Pasal $114 .{ }^{13}$

\section{METODE PENELITIAN}

Penelitian ini merupakan penelitian hukum yuridis normatif, sifat normatif penelitian hukum dikaitkan dengan karakter keilmuan itu sendiri. Karena itu pemilihan metode penelitian senantiasa dibatasi oleh rumusan masalah, objek yang diteliti dan tradisi keilmuan hukum itu sendiri.

Pendekatan penelitian yang digunakan dalam penelitian ini adalah pendekatan perundang-undangan (statute approach) dilakukan dengan cara

\footnotetext{
${ }^{9}$ Selengkapnya lihat Undang-Undang Nomor 35 Tahun 2009 Tentang Narkotika.

${ }^{10}$ Lihat selengkapnya pada Undang-Undang Nomor 35 tahun 2009 tentang Narkotika.

${ }^{11} \mathrm{R}$. Soesilo, Kitab Undang-Undang Hukum Pidana (KUHP) Serta Komentar-Komentar Lengkap Pasal Demi Pasal, Politea, Bogor, 1996, hlm. 34.

${ }^{12}$ Selain pidana mati, Undang-Undang Narkotika mengatur jenis-jenis sanksi pidana bagi penyalah guna narkotika, yaitu berbentuk pidana pokok berupa denda, kurungan, penjara (dalam waktu tertentu atau seumur hidup, termasuk pidana mati, serta pidana tambahan berupa pencabutan izin usaha atau pencabutan hak tertentu, atau pengusiran bagi warga negara asing.

${ }^{13}$ Selengkapnya lihat Pasal 114 Undang-Undang Nomor 35 Tahun 2009 Tentang Narkotika.
} 
menelaah semua undang-undang yang saling berkaitan dengan isu hukum yang diteliti, pendekatan konseptual (conceptual approach) dilakukan dengan cara menelaah pandangan-pandangan dari doktrin-doktrin yang berkembang di dalam ilmu hukum.

Dalam penelitian ini bahan-bahan hukum yang digunakan antara lain:

1. Bahan hukum primer

Bahan hukum primer adalah bahan-bahan hukum yang dijadikan dasar dalam menyusun penulisan penelitian yang diambil dari kepustakaan, diantaranya yaitu Undang-Undang Dasar Negara Republik Indonesia Tahun 1945, Undang-Undang Nomor 35 Tahun 2009 tentang Narkotika, UndangUndang Nomor 39 Tahun 1999 TentangHak Asasi Manusia dan Kitab Undang-Undang Hukum Pidana.

2. Bahan hukum sekunder

Bahan hukum sekunder yaitu bahan-bahan hukum yang merupakan hasil karya ilmiah para sarjana dan hasil-hasil penelitian, literatur karya dari para ahli hukum pidana secara umum, makalah dan literatur yang tersangkut dengan masalah yang akan dibahas.

3. Bahan hukum tertier

Bahan hukum tertier yaitu bahan hukum pendukung seperti kamus hukum, kamus bahasa Indonesia dan lain-lain.

\section{Analisis bahan hukum}

Analisis bahan hukum dilakukan dengan cara:

1. Menginterpretasikan semua peraturan perundang-undangan sesuai masalah yang dibahas.

2. Menilai bahan-bahan yang berhubungan dengan masalah yang akan diteliti.

3. Mengevaluasi perundang-undangan yang berhubungan dengan masalah yang dibahas.

\section{PEMBAHASAN}

Penerapan Pidana Mati Terhadap Pelaku Tindak Pidana Yang Mengedarkan Narkotika Berdasarkan Undang-Undang Nomor 35 Tahun 2009 Tentang Narkotika Pidana mati merupakan bagian dari jenis pidana yang berlaku berdasarkan hukum positif Indonesia. Bentuk pidana ini merupakan hukuman yang dilaksanakan dengan cara merampas jiwa seseorang yang melanggar ketentuan undang-undang.

Pelaksanaan eksekusi terpidana mati haruslah dilaksanakan setelah putusan pengadilan yang dijatuhkan padanya berkekuatan hukum tetap dan kepada si terpidana telah diberikan kesempatan untuk mengajukan semua upaya hukum, seperti banding, kasasi, peninjauan kembali dan megajukan grasi kepada presiden. Pelaksaan eksekusi dapat dilaksanakan dengan terlebih dahulu melalui persetujuan 
presiden. Pidana mati saat ini dijalankan dengan cara menembak mati si terpidana. Dalam hal ini eksekusi harus dihadiri Jaksa (Kepala Kejaksaan Negeri) sebagai eksekutor dan secara teknis pelaksanaan dilakukan oleh regu tembak kepolisian.

Pidana mati pada dasarnya dan seharusnya dijadikan sebagai sarana penal yang terakhir dan hanya dapat dipergunakan terhadap orang-orang yang melakukan kejahatan yang luar biasa (extra ordinary crime) tidak dapat dilakukan pembinaan lagi dan dirasa sangat membahayakan kehidupan masyarakat luas bahkan negara.

Beberapa ketentuan terpenting dalam pelaksanaan pidana mati adalah:

1. Tiga kali 24 jam sebelum pelaksanaan pidana mati, jaksa tinggi atau jaksa yang bersangkutan memberitahukan kepada terpidana dan apabila ada kehendak terpidana untuk mengemukakan sesuatu maka pesan tersebut diterima oleh jaksa;

2. Apabila terpidana sedang hamil harus ditunda pelaksanaannya hingga melahirkan;

3. Tempat pelaksanaan pidana mati ditentukan oleh Menteri Kehakiman di daerah hukum pengadilan hukum pengadilan tingkat I yang bersangkutan;

4. Kepala Polisi Daerah yang bersangkutan bertanggungjawab mengenai peksanaannya;

5. Pelaksanaan pidana mati dilaksanakan oleh suatu regu penembak polisis di bawah pimpinan seorang perwira polisi;

6. Kepala Polisi Daerah yang bersangkutan harus menghadiri pelaksanaan tersebut;

7. Pelaksanaan tidak boleh dimuka umum;

8. Penguburan jenazah diserahkan kepada keluarga;

9. Setelah selesai pelaksanaan pidana mati tersebut Jaksa yang bersangkutan hars membuat berita acara pelaksanaan pidana mati tersebut, yang kemudian salinan surat putusan tersebut harus dicantumkan ke dalam surat putusan pengadilan.

Ancaman pidana mati terhadap pengedar narkotika sebagaimana diatur dalam Undang-Undang Nomor 35 Tahun 2009 Tentang Narkotika pada Pasal 114 yang menentukan:

(1) Setiap orang yang tanpa hak atau melawan hukum menawarkan untuk dijual, menjual, membeli, menerima, menjadi perantara dalam jual beli, menukar atau menyerahkan narkotika golongan I, dipidana dengan pidana penjara seumur hidup atau pidana penjara paling singkat 5 (lima) tahun dan paling lama 20 (dua puluh) tahun dan pidana denda paling sedikit Rp. 1.000.000.000,- (satu milyar rupiah) dan paling banyak Rp. 10. 000.000.000,(sepuluh milyar rupiah)

(2) Dalam hal perbuatan menawarkan untuk dijual, menjual, membeli, menjadi perantara dalam jual beli, menukar, menyerahkan, atau menerima narkotika golongan I sebagaimana dimaksud pada ayat (1) yang dalam bentuk 
tanaman beratnya melebihi 1 (satu) kilogram atau melebihi 5 (lima) batang pohon atau dalam bentuk bukan tanaman beratnya 5 (lima) gram, pelaku dipidana dengan pidana mati, pidana penjara seumur hidup, atau pidana penjara paling singkat 6 (enam) tahun dan paling lama 20 (dua puluh) tahun dan pidana denda maksimum sebagaimana dimaksud pada ayat (1) ditambah $1 / 3$ (sepertiga).

Dalam penerapan hukuman mati, yang menjadi permasalahan adalah mengenai ketidakjelasan atau tidak adanya aturan mengenai waktu pelaksanaan eksekusi mati bagi terpidana mati itu sendiri, dalam hal ini terpidana mati pelaku pengedar narkotika

Problematika yang terjadi di Indonesia saat ini mengenai pidana mati, yaitu waktu yang berlarut-larut dalam proses eksekusi pidana mati itu sendiri. Hal ini terjadi karena tidak adanya ketentuan yang mengatur batas waktu pelaksanaan eksekusi pidana mati setelah adanya keputusan pengadilan yang berkekuatan hukum tetap. Kondisi ini terbentur dengan adanya hak terpidana/keluarganya untuk mengajukan upaya hukum luar biasa berupa PK (Peninjauan Kembali) ke Mahkamah Agung dan permohonan grasi kepada presiden.

Sebagai contoh terdapat beberapa kasus pengedar narkotika yang dieksekusi pidana mati. Pada 2005 berdasarkan putusan Mahkamah Agung Marco Archer Cardoso Moreira dijatuhi dengan pidana mati pelaksanaan ekseskusinya pada tahun 2015, kemudian Namaona Denis diputus pidana mati pada tahun 2002 dan pelaksanaan eksekusinya pada tahun 2015, Rani Andriani diputus pidana mati pada tahun 2001 dan pelaksanaan eksekusinya pada tahun 2015, Zainal Abidin diputus pidana mati pada tahun 2001 dan pelaksanaan eksekusinya pada tahun 2015, Raheem Agbaje Salami diputus pidana mati pada tahun 1999 dan pelaksanaan eksekusinya pada tahun 2015. ${ }^{14}$

Dari data tersebut nampak bahwa terdapat perbedaan dalam putusan pengadilan atau Mahkamah Agung tentang vonis bagi terpidana pengedar narkotika, dimulai dari tahun 1999 hingga tahun 2012. Namun dalam pelaksanaan eksekusi mati bagi terpidana mati kasus pengedar narkotika tersebut dilakukan pada tahun yang sama yakni pada awal tahun 2015.

Hal tersebut menunjukkan tidak adanya kejelasan atau kepastian hukum tentang rentang waktu pelaksanaan eksekusi pidana mati. Hal tersebut dikarenakan tidak adanya aturan yang mengatur tentang batas waktu pelaksanaan eksekusi mati bagi setiap terpidana mati di Indonesia, sehingga hal tersebut dapat menimbulkan ketidakpastian hukum bagi terpidana mati dalam hal ini terpidana mati kaus pengedar narkotika dan masyarakat. Oleh karena itu, sebaiknya pemerintah segera membuat kebijakan atau aturan tentang waktu pelaksanaan eksekusi mati, misal 5 (lima) tahun setelah vonis dijatuhkan. Hal tersebut perlu dilakukan agar semua upaya hukum (banding, kasasi, peninjauan kembali, dan grasi) dilakukan oleh

\footnotetext{
${ }^{14}$ Sumber data Mahkamah Agung RI
} 
terpidana mati dalam waktu sepuluh tahun karena untuk mengajukan upaya hukum luar biasa peninjauan kembali (PK) kepada Mahkamah Agung dan grasi kepada presiden atas terpidana mati tidak ada pembatasan waktu untuk pengajuannya, hal ini tentunya akan mempersulit bagi pihak kejaksaan dalam hal pelaksanaan eksekusi pidana mati bagi si terpidana mati itu sendiri. Disamping itu dengan ditetapkannya batas waktu pelaksanaan eksekusi mati tentunya akan memberikan kepastian hukum bagi terpidana mati dan masyarakat.

Untuk mengatasi hal tersebut pemerintah semestinya membuat aturan konkret mengenai pembatasan waktu untuk mengajukan Peninjauan Kembali kepada Mahkamah Agung dan grasi kepada Presiden bagi setiap terpidana mati terutama terpidana mati pengedar narkotika di Indonesia.

\section{Kebijakan Hukum Pidana Kedepan Dalam Pelaksanaan Pidana Mati Bagi Pengedar Narkotika}

Mahkamah Konstitusi melalui Putusan Nomor: 23/PUU-V/2007 Tentag Pengujian Undang-Undang Nomor 22 Tahun 1997 jo Undang-Undang Nomor 35 Tahun 2009 Tentang Narkotika terhadap UUD 1945 yang menolak permohonan para pemohon untuk menghapus pidana mati tidak hanya dalam kasus narkotika tetapi dari sistem pidana Indonesia.

Meskipun demikian, Mahkamah Konstitusi kemudian dalam putusan tersebut memberikan arahan agar konstruksi pidana mati ke depan memperhatikan hal-hal sebagai berikut:

1. Pidana mati bukan lagi merupakan pidana pokok, melainkan sebagai pidana yang bersifat khusus dan alternatif;

2. Pidana mati dapat dijatuhkan dengan masa percobaan selama 10 tahun yang apabila terpidana berkelakuan terpuji dapat diubah dengan pidana penjara seumur hidup atau selama 20 tahun;

3. Pidana mati tidak dapat dijatuhkan terhadap anak-anak yang belum dewasa;

4. Eksekusi pidana mati terhadap perempuan hamil dan seseorang yang sakit jiwa ditangguhkan sampai perempuan hamil tersebut melahirkan dan terpidana sakit jiwa tersebut sembuh.. ${ }^{15}$

Hal tersebut sesuai dengan Undang-Undang Nomor 35 Tahun 2009 Tentang Narkotika, yang menentukan penerapan pidana mati dapat dijatuhkan kepada orang yang melakukan tindak pidana narkotika jenis-jenis tertentu. Pengenaan pidana penjara seumur hidup atau pidana mati diterapkan kepada pelanggaran narkotika golongan I dan Golongan II dengan syarat tertentu sebagaimana yang diatur dalam undang-undang tersebut.

Kebijakan mengenai penerapan hukuman mati atau pelaksanaan eksekusi mati juga diatur dalam Rancangan Kitab Undang-Undang Hukum Pidana (KUHP). Sebagaimana dikatakan oleh Barda Nawawi Arief bahwa:

${ }^{15}$ Erdianto Effendi, Op. Cit., hlm. 156-157 
Namun, dalam kebijakan formulasinya juga mempertimbangkan perlindungan/kepentingan individu, yaitu dengan diadakannya ketentuan mengenai:

1. Penundaan pelaksanaan pidana mati atau pidana mati bersyarat, yaitu apabila dalam masa percobaan 10 (sepuluh) tahun terpidana menunjukkan sikap terpuji, pidana mati itu dapat diubah menjadi pidana penjara seumur hidup atau penjara 20 (dua Puluh) tahun (Pasal 82 Konsep 2000; Pasal 86 Konsep 2004).

2. Dapat diubahnya pidana penjara seumur hidup menjadi pidana penjara 15 (lima belas) tahun apabila terpidana telah menjalani pidana minimal 10 (sepuluh) tahun dengan berkelakuan baik (Pasal 65 Konsep 2000; Pasal 67 Konsep 2004) sehingga dimungkinkan terpidana mendapatkan pelepasan bersyarat (conditional release/parole). ${ }^{16}$

Dari penjelasan di atas dapat dikatakan bahwa kebijakan sistem hukum pidana yang berlaku di Indonesia (hukum positif) tetap mempertahankan penerapan hukuman mati bagi pelaku tindak pidana berat, seperti tindak pidana pengedar narkotika.

Dalam penerapan hukuman mati di Indonesia, pemerintah mesti segera memuat kebijakan atau aturan yang mengatur mengenai pelaksanaan eksekusi mati bagi terpidana mati, khususnya terpidana mati tindak pidana pengedar narkotika. Sesuai dengan formulasi yang telah dirumuskan dalam Rancangan KUHP dan arahan Mahkamah Konstitusi, maka dapat dikatakan pelaksanaan eksekusi mati dapat dilaksanakan setelah menjalani masa tahanan/penjara selama 10 tahun. Dalam waktu kurun tersebut terpidana mati diberi kesempatan untuk mengajukan segala upaya hukum, seperti banding, kasasi, peninjauan kembali, dan mengajukan grasi kepada presiden. Apabila terpidana mati menunjukkan sikap terpuji (berkelakuan baik) dalam masa 10 tahun tersebut, maka hukumannya dapat diubah menjadi hukuman penjara seumur hidup.

Waktu selama 10 tahun yang diberikan kepada terpidana mati untuk terpidana mengajukan segala upaya hukum dan menunjukkan sikap terpuji sebagaimana yang ditentukan dalam putusan Mahkamah Konstitusi dan Rancangan KUHP menurut peneliti merupakan waktu yang terlalu lama. Semestinya pemerintah membuat kebijakan, yakni memberikan waktu 5 tahun saja kepada terpidana mati untuk mengajukan segala upaya hukum, setelah sampai batas waktu 5 tahun jika upaya hukum yang diajukan siterpidana mati tidak diterima atau dikabulkan pemerintah harus melaksanakan eksekusi mati bagi terpidana mati tersebut.

Selain itu, peneliti tidak sependapat dengan adanya rencana pemerintah untuk merubah hukuman mati menjadi hukuman penjara seumur hidup bagi terpidana mati yang apabila dalam kurun waktu 10 tahun terpidana mati nenunjukkan sikap yang baik. Hal tersebut dikarenakan apabila terpidana mati pengedar narkotika

\footnotetext{
${ }^{16}$ Barda Nawawi Arief, Op.Cit., hlm. 288.
} 
dijatuhi hukuman seumur hidup, maka terbuka kemungkinan mereka akan kembali mengulangi perbuatannya dengan mengedarkan narkotika dibalik tembok penjara.

\section{KESIMPULAN DAN SARAN}

Penerapan hukuman mati bagi pengedar narkotika di Indonesia berdasarkan Undang-Undang Nomor 35 Tahun 2009 Tentang Narkotika telah sesuai dengan hukum positif yang berlaku di negara Indonesia, yakni sesuai dengan Pasal 10 KUHP. Penerapan hukuman mati bagi pelaku tindak pidana pengedar narkotika masih relevan dilaksanakan saat ini, hal tersebut dilakukan untuk menyelamatkan generasi penerus bangsa dan menyelamatkan bangsa dan negara Indonesia dari kehancuran yang diakibatkan oleh penyalahgunaan narkotika. Yang menjadi permasalahan saat ini adalah tidak adanya aturan yang mengatur mengenai batas waktu pelaksanaan eksekusi mati bagi terpidana mati di Indonesia, sehingga hal tersebut dapat menimbulkan ketidakpastian hukum bagi masyarakat terutama bagi terpidana mati itu sendiri, khususnya terpidana mati tindak pidana pengedar narkotika. Kebijakan kedepan dalam pelaksanaan pidana mati bagi pengedar narkotika masih perlu dilaksanakan karena hal tersebut telah sesuai dengan hukum dan undang-undang yang berlaku di Indonesia. Pelaksanaan eksekusi mati sebaiknya dilakukan setelah siterpidana mati melakukan semua upaya hukum dalam batas waktu 5 tahun.

Pemerintah bersama Dewan Perwakilan Rakyat hendaknya segera menyelesaikan dan mengesahkan rancangan KUHP dan memuat ketentuan tentang sanksi pidana mati bagi kejahatan tertentu, seta memuat ketentuan mengenai waktu pelaksanaan eksekusi mati bagi terpidana mati yang ada di Indonesia khususnya terpidana mati tindak pidana mpengedar narkotika agar memberikan kepastian hukum..

\section{DAFTAR PUSTAKA}

\section{BUKU}

Adami Chazawi, Pelajaran Hukum Pidana Bagian I, Raja Grafindo Persada, Jakarta, 2002.

Barda Nawawi Arief, Kebijakan Hukum Pidana, Prenada Media Group, Jakarta, 2011.

Barda Nawawi Arief, Masalah Penegakan Hukum dan Kebijakan Hukum Pidana Dalam Penanggulangan Kejahatan, Prenada Media Group, Jakarta, 2010.

Jimly Asshiddiqie, Pengantar Hukum Tata Negara, Raja Grafindo Persada, Jakarta, 2012.

Jimly Asshiddiqie, Pokok-Pokok Hukum Tata Negara Indonesia Pasca Reformasi, PT. Bhuana Ilmu Populer, Jakarta, 2008. 
J.E. Sahetapy, Pidana Mati Dalam Negara Pancasila, Citra Aditya Bhakti, Bandung, 2007

Koesno Adi, Diversi Tindak Pidana Narkotika Anak, Setara Press, Jatim, 2014.

Mexsasai Indra, Dinamika Hukum Tata Negara Indonesia, Refika Aditama, Bandung, 2011.

R. Soesilo, Kitab Undang-Undang Hukum Pidana (KUHP) Serta Komentar-Komentar Lengkap Pasal Demi Pasal, Politea, Bogor, 1996.

Siswanto, Politik Hukum Dalam Undang-Undang Narkotika, PT. Rineka Cipta, Jakarta, 2012.

Siswanto Sunarso, Penegakan Hukum Psikotropika Dalam Kajian Sosiologi Hukum, Raja Grafindo Persada, Jakarta, 2004.

\section{Peraturan Perundang-Undangan}

Republik Indonesia, Undag-Undang Dasar Negara Republik Indonesia Tahun 1945. Republik Indonesia, Undang-Undang Nomor 35 Tahun 2009 Tentang Narkotika. Republik Indonesia, Undang-Undang Nomor 39 Tahun 1999 Tentang Hak Asasi Manusia.

Republik Indonesia,Kitab Undang-Undang Hukum Pidana. 